\title{
Modelling and Control of Corticotropin Permeation from Hydrogels across a Natural Membrane in the Presence of Albumin
}

\author{
Wioletta Siemiradzka ${ }^{1, *(D)}$, Barbara Dolińska ${ }^{1,2, *}$ and Florian Ryszka ${ }^{2,+}$ \\ 1 Department of Pharmaceutical Technology, Faculty of Pharmaceutical Sciences in Sosnowiec, \\ Medical University of Silesia, Kasztanowa 3, 41-200 Sosnowiec, Poland \\ 2 "Biochefa" Pharmaceutical Research and Production Plant, Kasztanowa 3, 41-200 Sosnowiec, Poland \\ * Correspondence: wsiemiradzka@sum.edu.pl (W.S.); bdolinska@sum.edu.pl (B.D.); \\ Tel.: +48-32-269-98-20 or +48-32-269-98-21 (W.S.) \\ + Prof. F. Ryszka is co-author, but he recently died.
}

check for updates

Citation: Siemiradzka, W.; Dolińska, B.; Ryszka, F. Modelling and Control of Corticotropin Permeation from Hydrogels across a Natural Membrane in the Presence of Albumin. Processes 2021, 9, 1674. https://doi.org/10.3390/pr9091674

Academic Editor: Alina Pyka-Pająk

Received: 29 July 2021

Accepted: 14 September 2021

Published: 18 September 2021

Publisher's Note: MDPI stays neutral with regard to jurisdictional claims in published maps and institutional affiliations.

Copyright: (C) 2021 by the authors. Licensee MDPI, Basel, Switzerland. This article is an open access article distributed under the terms and conditions of the Creative Commons Attribution (CC BY) license (https:// creativecommons.org/licenses/by/ $4.0 /)$.

\begin{abstract}
Background: Skin is a difficult barrier to overcome, especially for molecules with masses greater than $500 \mathrm{Da}$. It has been suggested that albumin may contribute to more effective penetration of many therapeutic substances. In this study, an attempt was made to use albumin in semi-solid formulations to increase the skin penetration of another peptide-corticotropin (ACTH). (2) Methods: Hydrogels were prepared at two concentrations: $15 \mathrm{mg} / \mathrm{g}$ and $20 \mathrm{mg} / \mathrm{g}$ corticotropin, then albumin was added to them in different stoichiometric ratios. The degree of ACTH release from hydrogels, both with and without albumin addition, was investigated. For selected hydrogels the process of corticotropin permeation through a model membrane, i.e., pig skin, was examined. (3) Results: The study of corticotropin release showed that the addition of albumin, depending on its amount, may delay or increase the release process. Similarly, a study of ACTH permeation through porcine skin showed that albumin can delay or increase and accelerate ACTH permeation. (4) Conclusions: Hydrogel, applicated on the skin surface, may prove to be a beneficial and convenient solution for patients. It is an innovative way of application ACTH that bypasses the gastrointestinal tract and may result in increased availability of the peptide and its efficacy.
\end{abstract}

Keywords: corticotropin; albumin; transdermal dosage form; release/permeation process; spectrophotometric determination; rheological stability

\section{Introduction}

$\mathrm{ACTH}$, an adrenocorticotropic hormone with a molecular weight of approximately $4.5 \mathrm{kDa}$, is produced and then secreted by the hypothalamic pituitary gland [1,2]. The functions of ACTH include regulation of cortisol production [3].

Normal plasma adrenocorticotropic hormone levels are 1.5-11 pmol/L in men and 1.1-5.9 $\mathrm{pmol} / \mathrm{L}$ in women [4].

Corticotropin is used in autoimmune diseases such as polymyositis, systemic lupus, symptomatic sarcoidosis, or rheumatoid arthritis, as well as Crohn's disease and ulcerative colitis [5,6]. Moreover, many studies on the possible use of ACTH in other clinical cases are being conducted [6].

There is growing evidence that ACTH can be used to control corticotropin-releasing factor (CRF) levels, which are affected by Alzheimer's disease (AD), to enhance memory and delay AD progression [7]. ACTH therapy has been shown to delay disease progression and reduce symptoms [8,9].

It has also been reported that ACTH has been shown to give better results than intravenous methylprednisolone in supportive treatment for multiple sclerosis [10].

It has been suggested that it may be possible to make preparations with ACTH for application to the skin to achieve a therapeutic effect. The process of ACTH release has been 
investigated [11,12], and it has been observed that the amount of corticotropin released from the hydrogel is closely dependent on its concentration [11,12].

A special role among biocompatible polymeric materials that can act as a carrier for a therapeutic substance is attributed to albumin. Albumin has the ability to transport low molecular weight substances, including to target organs. Due to its large size, it allows low-molecular substances to be retained within the affected tissue. The permeability of the affected tissue is often impaired, which may even result in accumulation of the active substance inside the tumour. It is albumin that allows such a beneficial change in the fate of the drug in the body [13-16].

Human serum albumin (HSA) accounts for $50 \%$ of all plasma proteins. Blood albumin ranges from 3.5 to $5.0 \mathrm{~g} / \mathrm{dL}$. HSA is a globular protein consisting of $585 \mathrm{amino}$ acid residues. The molecular weight of albumin is $66.5 \mathrm{kDa}$ [17].

The embedding of anticancer drugs in nanoparticles reduces the toxicity of chemotherapy, contributes to the accumulation of conjunctions with solid biologically active substances, increases drug solubility and improves pharmacokinetics [18-21].

Albumin can be used to formulate conjugates, nanoparticles and complexes with drugs, antibodies, and peptides. Examples of such applications of albumin may be: Levemir ${ }^{\circledR}$, i.e., insulin combined with albumin used in the treatment of diabetes, nanoparticle Abraxane ${ }^{\circledR}$, which is a combination of albumin and paclitaxel indicated in the treatment of breast cancer metastases, or Nanocol ${ }^{\circledR}$ and Albures ${ }^{\circledR}$, agents containing technetium 99Tc isotope used in the diagnosis of cancer and cancer metastases. Such compounds provide improved pharmacokinetics, resistance to degradation in the body and, therefore. longer half-life, faster dissolution, and increased penetration to the target site (e.g., tumour) [22-24].

In medicine, albumin is used to treat shock, burns, hypoalbuminaemia, oedema, as well as after surgical trauma, arthritis, etc. [13-15]. However, there are few reports on the penetration of albumin through natural membranes [25]. Due to the difficulty of peptides as large molecules to overcome the skin barrier, we considered the possibility of using human albumin as a substance to model ACTH penetration through the skin. Therefore, the object of this paper is to investigate the effect of albumin on the permeation of ACTH through the skin. This aim was achieved by preparing hydrogels with ACTH in two concentrations $15 \mathrm{mg} / \mathrm{g}$ and $20 \mathrm{mg} / \mathrm{g}$. Then, each hydrogel with ACTH was loaded with human albumin solution in three different concentrations in order to maintain the following steichiometric ratios with respect to corticotropin: 1:1, 1:0.1 and 1:0.01.

The physicochemical properties and the release process of ACTH from hydrogel formulations using a cellulose membrane were investigated in the prepared hydrogels.

The ACTH permeation process was carried out and analysed using a natural membrane such as porcine skin.

\section{Materials and Methods}

\subsection{Materials}

The study material was: corticotropic hormone isolated from pig pituitary glands in freeze-dried form, easily soluble in water with activity of $90 \mathrm{IU} / \mathrm{mg}$ "Biochefa" Pharmaceutical Research and Production Plant, Poland) and human albumin (Human Albumin 200 g/L, CSL Behring GmbH, Marburg, Germany, with composition: 200 g/L total protein, including at least $96 \%$ human albumin, sodium caprylate, sodium N-acetyl-D, L-tryptophan, sodium chloride, sodium hydroxide, water for injection.

Excipients: wheat starch (Galfarm, Kraków, Poland), glycerol 85\% (Galfarm, Kraków, Poland), purified water (Fagron, Kraków, Poland), (Avantor Performance Material S.A., Gliwice, Poland), disodium hydrogen phosphate (Avantor Performance Material S.A., Gliwice, Poland), potassium dihydrogen phosphate (Avantor Performance Material S.A., Gliwice, Poland). The substances used were of the PD class and meet the requirements of standards for pharmaceutical raw materials. 


\subsection{Formulation of the Hydrogel Base}

Hydrogel formulation (F-1) was made according to Polish Pharmacopoeia VI [26]. This base includes wheat starch (8.6 g), Glycerol 85\% (77.6 g), and purified water (13.8 g). Wheat starch is suspended in purified water and glycerol heated to approximately $60{ }^{\circ} \mathrm{C}$ is added by stirring. The mixture prepared in this way was heated by continuous stirring until a homogeneous, translucent mass was formed. The hydrogel medium prepared in this way was stored at $4.0^{\circ} \mathrm{C}$.

\section{Preparation of the Hydrogel Formulations}

A total of eight formulations of hydrogels with corticotropin were prepared: two with two different concentrations of ACTH-15 mg and $20 \mathrm{mg}$ per $1 \mathrm{~g}$ of hydrogel and three with albumin in different quantitative ratios with ACTH-1:1, 1:0.1 and 1:0.01. The hydrogels were prepared using CITO e/s Unguator, taking the following parameters: time-2 min, rotation $720 \mathrm{rpm}$. Corticotropin dissolved in small amount of glycerol was added to the previously prepared medium and homogenised. Then the solution of albumin was added to the hydrogel with ACTH and mixed thoroughly as well. The hydrogel with albumin (F-10) was prepared by introducing albumin solution into the hydrogel base and mixing in the Unguator at $720 \mathrm{rpm}$ for $2 \mathrm{~min}$. The prepared hydrogel was stored in tightly closed containers in a refrigerator at $4.0^{\circ} \mathrm{C}$. Table 1 shows the composition of hydrogels prepared on the basis of glycerol hydrogel containing ACTH itself, albumin and ACTH together with albumin. A hydrogel containing albumin itself was used only as a reference in the porcine skin permeation test.

Table 1. Composition of prepared hydrogel formulations F-1-F-10 per $10 \mathrm{~g}$ of hydrogel.

\begin{tabular}{cccc}
\hline Ingredient & ACTH $(\mathbf{m g})$ & Albumin $(\mathbf{m g})$ & Glycerol Hydrogel \\
\hline Formulation & & & + \\
F-1 & - & - & + \\
F-2 & 150.0 & - & + \\
F-3 & 150.0 & 150.0 & + \\
F-4 & 150.0 & 15.0 & + \\
F-5 & 150.0 & 1.5 & + \\
F-6 & 200.0 & - & + \\
F-7 & 200.0 & 200.0 & + \\
F-8 & 200.0 & 20.0 & + \\
F-9 & 200.0 & 2.0 & + \\
F-10 & - & 150.0 & + \\
\hline
\end{tabular}

\section{3. $p H$ Testing by Potentiometric Method}

The particular quality of the drug in the form of a dermatological hydrogel requires a pH test, which is performed using the potentiometric method (FP XI)-Polish Pharmacopoeia, edition XI, 2017 [27] by directly connecting a glass electrode in the semi-solid preparation. An InLab Expert Pro-ISM electrode, catalogue number 30014096, MettlerToledo AG, Greifensee, Switzerland, was used for the study.

Measurements at temperature $25.0 \pm 0.5^{\circ} \mathrm{C}$ were taken for the base-glycerol hydrogel F-1 and prepared formulations F-2-F-9.

\subsection{Corticotropin Release Study}

To examine the kinetics of corticotropin release from prepared hydrogels (F-1-F-9), the Erweka DT 600 vane apparatus according to USP 2, equipped with a set of fluoropolymer enhancement cells, $200 \mathrm{~mL}$ round-bottomed vessel and mini $\mathrm{HH}$ paddle, was used. Excess hydrogel was placed in special enhancer cells with an exposed surface of $3.80 \mathrm{~cm}^{2}$. The surface of the hydrogel was leveled with a spatula and then the overflow was removed, after which the exact amount of hydrogel was defined by weight. As a result, $1.0 \mathrm{~g}$ of hydrogel with the required amount of active substance was applied to the enhancer 
cells. The membrane imitating Spectra/Por ${ }^{\circledR} 2$ Dialysis Membrane MWCO was covered: $100 \mathrm{kDa}$, from Spectrum Labs, previously soaked $30 \mathrm{~min}$ in purified water. Phosphatebuffered sodium chloride-PBS (Disodium hydrogen phosphate, potassium dihydrogen phosphate, sodium chloride, sodium hydroxide and water). The volume of acceptor fluid was $50 \mathrm{~mL}$. The acceptor fluid environment was similar to physiological, with a $\mathrm{pH}$ of 7.4. The temperature was maintained at $32{ }^{\circ} \mathrm{C}$ throughout the test. The speed of the stirrers was 50 revolutions per minute. The test was conducted for $360 \mathrm{~min}$. Five replicates were performed for each hydrogel formulation. Samples of $3 \mathrm{~mL}$ were taken after: 5,10 , $15,20,30,45,60,90,120,150,180,210,240,270,300,330$ and $360 \mathrm{~min}$. The volume of samples after each sampling for measurements was supplemented to $50 \mathrm{~mL}$. The amount of released corticotropin was determined in the collected samples. The amount of hormone released per unit time was calculated and release profiles were plotted. The method of corticotropin determination was described by Siemiradzka et al. [11,12]. Measurements were made using a UV-VIS Cecil CE 3021 spectrophotometer (Cecil Instruments Limited, Cambridge, England). The ACTH content was calculated from the standard curve with equation $\left.\mathrm{y}=0.6925 \mathrm{x}-0.0123 ; \mathrm{R}^{2}=0.9996 ; p<0.01\right)[11,12]$.

\subsection{Skin Permeation Study in Simulated In Vivo Conditions}

\subsubsection{Vertical Franz Diffusion Cells}

Franz diffusion cells (Xenometrix, Allschwil, Switzerland) with an inner diameter of $15 \mathrm{~mm}$ and a permeation area of $1.77 \mathrm{~cm}^{2}$ were used for the penetration study (Figure 1). A $0.5 \mathrm{~g}$ sample was placed on the membrane in the donor chamber. To avoid drying of the hydrogel, the Franz chamber was covered from above with parafilm. The acceptor chamber was filled with $12 \mathrm{~mL} \mathrm{PBS,} \mathrm{pH} 7.4$, and the temperature was maintained at $32{ }^{\circ} \mathrm{C}$ by placing the protected Franz chambers in a water bath. Control of the temperature was performed in the collected samples. After times of 1, 2, 3, 4, 5, 6 and $24 \mathrm{~h}, 2 \mathrm{~mL}$ samples were taken each and made up to $12 \mathrm{~mL}$ of PBS at $32{ }^{\circ} \mathrm{C}$. The amount of corticotropin permeated was determined spectrophotometrically at a wavelength, $\lambda=276.5 \mathrm{~nm}$, using PBS solution as a reference. The mean of five replicates was calculated. Corticotropin content was calculated from a standard curve with the equation $y=0.6925 x-0.0123 ; R^{2}=0.9996[11,12]$. The total cumulative amount was presented as the amount permeated per unit skin area $\left[\mathrm{mg} / \mathrm{cm}^{2}\right]$ in $24 \mathrm{~h}$. The concentration of albumin in collected samples was determined using a validated spectrophotometric method. In order to determine the maximum absorption of albumin, an albumin solution of $1 \mathrm{mg} / \mathrm{mL}$ was prepared in phosphate-buffered sodium chloride (PBS), $\mathrm{pH}=7.4$. From the spectrum recorded in the wavelength range $\lambda=200-400 \mathrm{~nm}$, the maximum absorption was determined. The developed spectrophotometric method was specific for the determination of the corresponding protein-peptide substance.

The linearity of the method was determined on the basis of 3-fold measurements of the absorbance of albumin solutions in 10 concentrations in the range from 0.0 to $1.0 \mathrm{mg} / \mathrm{mL}$ at the determined wavelength and described by the linear regression equation $y=a x+b$. Phosphate-buffered sodium chloride was used as a reference. Based on the results obtained, a calibration curve was plotted for the dependence of absorbance on albumin concentration. The significance of the fit of the equation to the experimental data was described by the correlation coefficient $\left(\mathrm{R}^{2}\right)$. Absorbance measurements were made in $1 \mathrm{~cm}$ quartz cuvettes using UV-VIS Cecil CE 3021 spectrophotometer (Cecil Instruments Limited, Cambridge, UK). The photometric accuracy was $\pm 0.005 \mathrm{~A}$. Measurement were repeated 5 times. The amount of permeated albumin was determined by spectrophotometric measurement at the wavelength, $\lambda=279 \mathrm{~nm}$, The albumin content was calculated from a standard curve with the equation $y=0.7765 x-0.0101 ; R^{2}=0.9994$. Permeation rate was calculated per skin surface unit $\left[\mathrm{mg} / \mathrm{cm}^{2}\right]$ within $24 \mathrm{~h}$. 


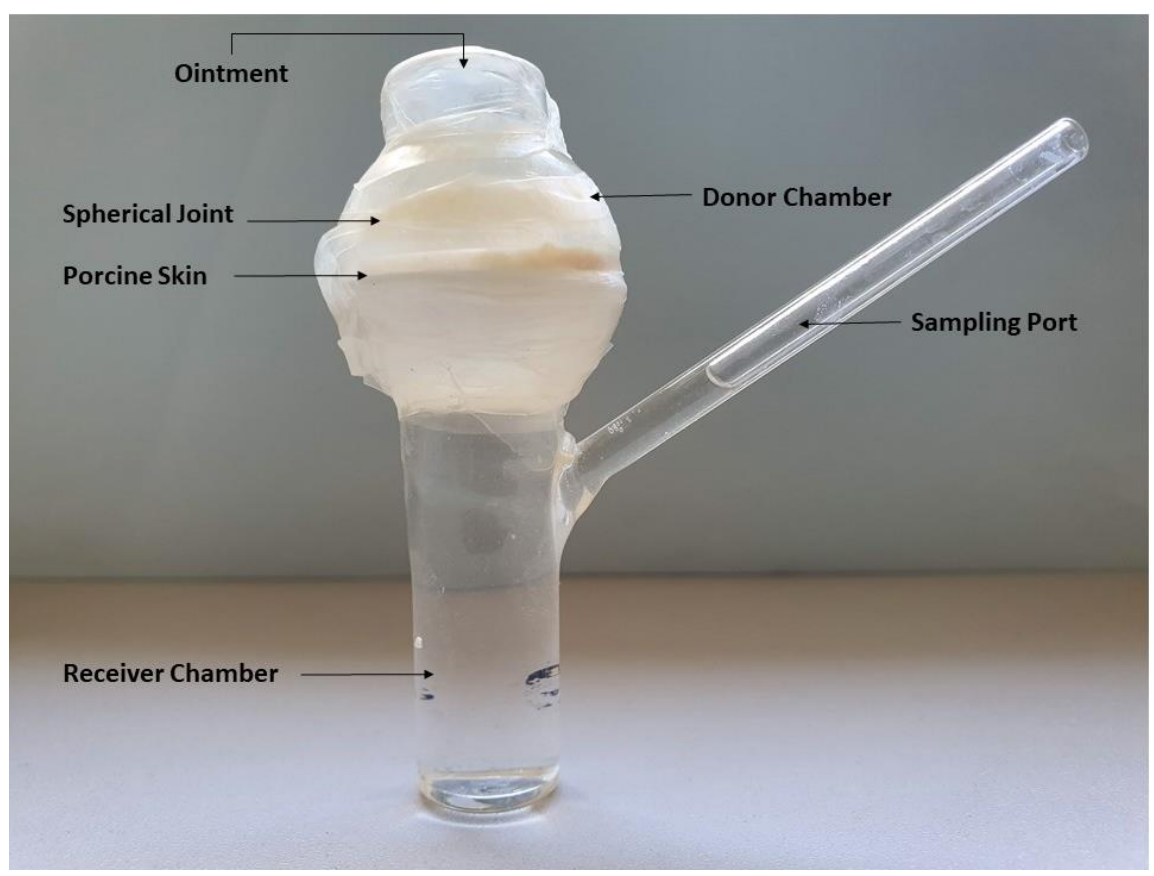

Figure 1. The scheme of vertical Franz cell with a spherical joint to ACTH penetration study through porcine ear skin in simulated in vivo conditions.

\subsubsection{Skin Preparation}

Due to the lower availability and difficulties associated with the use of human skin ex vivo, porcine skin was used to study the ACTH permeation profile. Pig skin is a suitable membrane due to its similarity in thickness and permeability properties to human skin [28]. The model membrane for the skin permeation study was pig ear skin obtained from a local rancher. The skin was washed with $0.9 \% \mathrm{NaCl}$ solution to an absorbance of $\mathrm{E}<0.02$ at $\lambda=276.5 \mathrm{~nm}$ and dried with a paper towel. Hair was carefully cut with scissors so as not to harm the stratum corneum, and the subcutaneous fat layer was removed with a scalpel. Full thickness skin samples were wrapped in aluminium foil and stored at $-20^{\circ} \mathrm{C}$. Skin sections were cut to a diameter of $2.5 \pm 0.5 \mathrm{~cm}^{2}$. Each preparation was applied to an area of skin.

\subsection{Rheology}

Rheological studies were carried out using the Lamy Rheology Instruments' (Champagne au Mont d'Or, France) RM 200 Touch universal rotational rheometer for testing rheological properties of samples, equipped with the Lamy Rheology Instruments' (Champagne au Mont d'Or, France) CP1 Plus thermostat with Rheomatic Lamy Instruments software. The tests were carried out in a plate to plate system using the MS CP 2445 measuring system of Lamy Rheology Instruments (Champagne au Mont d'Or, France) with a diameter of $24 \mathrm{~mm}, \alpha=0.45^{\circ}$. Before the measurement the samples were placed in a CLW 53 STD, POL-EKO Aparatura sp.j., Wodzisław Śląski, Poland, at a temperature of $32.0 \pm 0.5^{\circ} \mathrm{C}$. After $30 \mathrm{~min}$ the sample was placed on the bottom plate of a thermostatic system with the Peltier effect, made of stainless steel, and lowered the top plate. The gap between the plates was $50 \mu \mathrm{m}$. The excess sample was removed with a spatula. All rheological tests were performed at $32.0 \pm 0.5^{\circ} \mathrm{C}$. Preliminary shearing was performed at a shear rate of $5 \mathrm{~s}^{-1}$ for $15 \mathrm{~s} 2 \mathrm{~min}$ after sample application. Viscosity was measured for the tested hydrogels at two shear rates: $15 \mathrm{~s}^{-1}$ and $30 \mathrm{~s}^{-1}$, the flow test was performed at the shear rate $\mathrm{D}=5-200 \mathrm{~s}^{-1}$ during $30 \mathrm{~s}$ and the shear stress was measured in relation to the shear rate ("step by step") at the shear rate $\mathrm{D}=10-200 \mathrm{~s}^{-1}$. The number of measurement points performed at equal intervals-every $10 \mathrm{~s}$-was 12 for each curve at increasing and decreasing shear rate. The test was performed for the substrate-glycerol hydrogel, for 
hydrogels containing ACTH (15 mg/g and $20 \mathrm{mg} / \mathrm{g}$ ) and for hydrogels containing ACTH and albumin in ratios 1:1, 1:0.1 and 1:0.01. All measurements were repeated 5 times $(n=5)$.

\subsection{Statistical Analysis}

Based on the results obtained, mean values were calculated together with the standard deviation and subjected to statistical analysis using Microsoft's Excell package and Statistica (StatSoft, Inc. Tulsa, OK, USA): Industrial Analysis, Experiment Design (DOE) program. The results were also analysed with Statistica Pharmaceutical Kit: Statistica "Release Profiles" Weibull method. Statistical significance at $p<0.05$ was evaluated using Student's $t$-test.

\section{Results}

\subsection{Measurement of the $p H$ Value}

$\mathrm{pH}$ values of obtained hydrogels are presented in Table 2.

Table 2. $\mathrm{pH}$ values of obtained hydrogel base, ACTH formulations and ACTH with albumin formulations, $(n=3)$.

\begin{tabular}{cc}
\hline Formulation & pH \pm SD \\
\hline F-1 & $4.955 \pm 0.021$ \\
F-2 & $5.990 \pm 0.028$ \\
F-3 & $5.485 \pm 0.007$ \\
F-4 & $5.425 \pm 0.021$ \\
F-5 & $5.255 \pm 0.035$ \\
F-6 & $6.240 \pm 0.014$ \\
F-7 & $5.605 \pm 0.007$ \\
F-8 & $5.510 \pm 0.014$ \\
F-9 & $6.135 \pm 0.021$ \\
\hline
\end{tabular}

The $\mathrm{pH}$ values of the hydrogels are close to the acidic character. The lowest $\mathrm{pH}$ value was observed for glycerol hydrogel as a base (F-1), whereas the highest for hydrogels containing adrenocorticotropic hormone, depending on ACTH concentration for concentration of $15 \mathrm{mg} / \mathrm{g} \mathrm{pH}=5.99 \pm 0.028$ (F-2) and higher for concentration of $20 \mathrm{mg} / \mathrm{g}$, $\mathrm{pH}=6.24 \pm 0.014$ (F-6). The results obtained allow us to state that adding ACTH to the glycerol hydrogel increases the $\mathrm{pH}$ value. On the other hand, the addition of albumin at any concentration causes a decrease in $\mathrm{pH}$ value in comparison with glycerol hydrogel with $\mathrm{ACTH}$, the more albumin, the lower the $\mathrm{pH}$ value. The $\mathrm{pH}$ values of the obtained hydrogels are similar to the $\mathrm{pH}$ value of the skin (4.5-6.5), so they can be safely applied to the skin without causing irritation.

The $\mathrm{pH}$ value as well as temperature-dependent gelation conditions for bovine serum albumin (BSA-bovine serum albumin) and human albumin (HSA-human serum albumin) have been studied by Arabi et al., 2018 [29]. The researchers confirmed that gelation of BSA and HSA can occur in a wide range of $\mathrm{pH}$ and temperatures $(\mathrm{pH} 1.0-4.3$ and $\mathrm{pH}>10.6$ at $37^{\circ} \mathrm{C}$ or $\mathrm{pH} 7.0-7.2$ at $50-65^{\circ} \mathrm{C}$ ). Hydrogen ions required during PBSA hydrogel formation (electrostatically $(\mathrm{pH})$ triggered BSA hydrogels) can be neutralised so that product obtained has a physiological $\mathrm{pH}$ of 7.4. PBSA hydrogel remains stable for up to three months [30].

\subsection{Corticotropin Release Study from the Hydrogels}

For studies, the release of ACTH from the obtained hydrogels, USP 2, Enhancer cells were used due to the possibility of release into a smaller volume of acceptor fluid. It is believed that the release of the active substance is determined by the properties of the membrane through which the substance penetrates into the acceptor environment. Thus, depending on the properties of the therapeutic substance, the drug formulation and the route of its administration, the release study can be performed in different fluids. Phosphate-buffered sodium chloride, $\mathrm{pH} 7.4$, was used as the acceptor fluid. 
In the release investigation, it was observed that from hydrogel of $15 \mathrm{mg} / \mathrm{g}, \mathrm{ACTH}$ $2.28 \pm 0.05 \mathrm{mg} / \mathrm{cm}^{2}$ was released (Figure 2A), whereas from hydrogel of $20 \mathrm{mg} / \mathrm{g}$ ACTH 1.2 times more corticotropin was released $-2.79 \pm 0.15 \mathrm{mg} / \mathrm{cm}^{2}$ compared to hydrogel of $15 \mathrm{mg} / \mathrm{g}$ ACTH (Figure 2B). However, referring to the fraction of dose placed on the cellulose membrane, increasing the dose from 15 to $20 \mathrm{mg} / \mathrm{g}$ (1.33 times) did not result in a corresponding increase in the amount of ACTH released. The amount of corticotropin released was $58 \%$ for $15 \mathrm{mg} / \mathrm{g}$ and $53 \%$ for $20 \mathrm{mg} / \mathrm{g}$. 1.1 times more ACTH was observed from the lower concentration hydrogel. The addition of albumin in a 1:1 ratio to ACTH significantly increased ACTH release at the lower concentration of $15 \mathrm{mg} / \mathrm{g}$ by 1.4-fold, from $2.28 \pm 0.05 \mathrm{mg} / \mathrm{cm}^{2}$ to $3.11 \pm 0.19 \mathrm{mg} / \mathrm{cm}^{2}$. In the case of a higher concentration $-20 \mathrm{mg} / \mathrm{g}$, initially albumin decreased the release of ACTH from the hydrogel, only after $180 \mathrm{~min}$ a positive effect of albumin on the increase in released ACTH was noted. The released ACTH increased from $2.79 \pm 0.15 \mathrm{mg} / \mathrm{cm}^{2}$ to $3.18 \pm 0.09 \mathrm{mg} / \mathrm{cm}^{2}$, but the difference was not statistically significant.
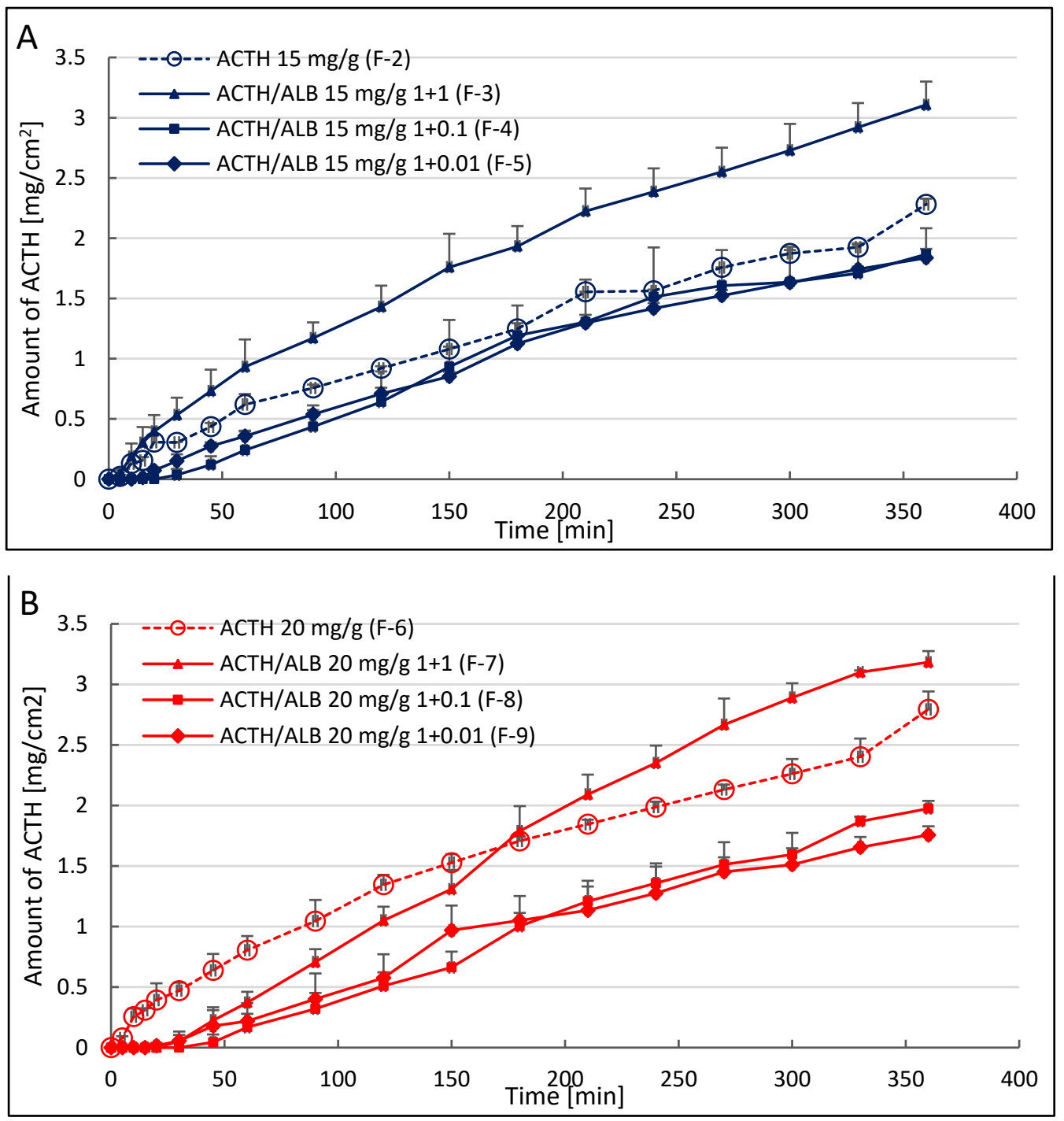

Figure 2. Corticotropin (ACTH) release profiles for formulations with ACTH at $15 \mathrm{mg} / \mathrm{g}$ (F-2) and ACTH at $15 \mathrm{mg} / \mathrm{g}$ and albumin (F-3-F-5) (A) and for formulations with ACTH at $20 \mathrm{mg} / \mathrm{g}$ (F-6) and for formulations with ACTH at $20 \mathrm{mg} / \mathrm{g}$ and albumin (F-7-F-9) (B).

The Weibull method $(p<0.05)$ showed statistically significant differences in ACTH release profiles from the obtained hydrogels $(p<0.05)$. The regression coefficients are presented in Table 3. Correlation coefficients for pharmacokinetic models of ACTH release 
from hydrogels are also presented in Table 3. In the present study, a time interval of $15 \mathrm{~min}$ to $360 \mathrm{~min}$ was to model the drug release rate. The drug permeation rate and applicability of the Higuchi model for all hydrogel formulations of peptide hormone was inferred from an $\mathrm{R}^{2}$ value of approximately 0.99 for all formulations according to the Higuchi model. For calculation of ACTH release rate from the hydrogel, the Higuchi model was used (Table 4).

Table 3. Kinetic release models fitted to describe the release of ACTH from obtained hydrogel for formulations F-2-F-9.

\begin{tabular}{lcccc}
\hline \multicolumn{1}{c}{ Formulation } & First Order & Higuchi Model & Korsmeyer-Peppas Model & Weibull Method \\
\hline & \multicolumn{3}{c}{ Regression Coefficient $\mathbf{R}^{\mathbf{2}}$} \\
\hline F-2 (15 mg/g ACTH) & 0.9845 & 0.9838 & 0.9504 & 0.9630 \\
F-3 (15 mg/g ACTH + 15 mg/g ALB) & 0.9780 & 0.9965 & 0.9466 & 0.9710 \\
F-4 (15 mg/g ACTH + 1.5 mg/g ALB) & 0.9782 & 0.9973 & 0.9458 & 0.9610 \\
F-5 (15 mg/g ACTH + 0.15 mg/g ALB) & 0.9886 & 0.9906 & 0.9227 & 0.9400 \\
F-6 (20 mg/g ACTH) & 0.9736 & 0.9922 & 0.9085 & 0.9860 \\
F-7 (20 mg/g ACTH + 20 mg/g ALB) & 0.9923 & 0.9888 & 0.9505 & 0.9710 \\
F-8 (20 mg/g ACTH + 2.0 mg/g ALB) & 0.9898 & 0.9908 & 0.9129 & 0.9580 \\
F-9 (20 mg/g ACTH + 0.2 mg/g ALB) & 0.9857 & 0.9824 & \\
\hline
\end{tabular}

Table 4. ACTH release rate and fit using Higuchi's model $(n=6)$ in vitro condition; ${ }^{*}<0.05$ applies to F-2 (15 mg/g ACTH) and ${ }^{* *} p<0.05$ applies to F-6 (20 mg/g ACTH).

\begin{tabular}{|c|c|c|c|c|c|}
\hline Formulation & $\begin{array}{l}\text { Average Release Rate } \\
\left(\mathrm{mg} / \mathrm{cm}^{2} / \mathrm{min}^{1 / 2}\right) \pm \mathrm{SD}\end{array}$ & $\mathbf{R}^{2}$ & Formulation & $\begin{array}{l}\text { Average Release Rate } \\
\left(\mathrm{mg} / \mathrm{cm}^{2} / \mathrm{min}^{1 / 2}\right) \pm \mathrm{SD}\end{array}$ & $\mathbf{R}^{2}$ \\
\hline F-2 (15) & $0.120 \pm 0.003$ & 0.9838 & F-6 (20) & $0.147 \pm 0.008$ & 0.9922 \\
\hline F-3 (15 1:1) & $0.164 \pm 0.010$ * & 0.9965 & F-7 (20 1:1) & $0.168 \pm 0.005^{* *}$ & 0.9888 \\
\hline F-4 (15 1:0.1) & $0.098 \pm 0.005^{*}$ & 0.9873 & F-8 (20 1:0.1) & $0.104 \pm 0.003^{* *}$ & 0.9849 \\
\hline F-5 (15 1: 0.01) & $0.097 \pm 0.004$ * & 0.9906 & F-9 (20 1:0.01) & $0.093 \pm 0.004^{* *}$ & 0.9615 \\
\hline
\end{tabular}

The most advantageous formulation was hydrogel with lower concentration of ACTH $(15 \mathrm{mg} / \mathrm{g})$, with addition of albumin in ratio $1: 1(15 \mathrm{mg} / \mathrm{g})$, because albumin significantly increased the amount of released ACTH and for this preparation, the process of penetration through the natural membrane which is porcine skin was examined.

Tazhbayev et al. produced urea- and cysteine-stabilised HSA nanoparticles and incorporated anticancer drugs into them. Urea, as a natural denaturant, expands the biopolymer molecule and facilitates cysteine access to the molecule to interact with protein molecules. The performance of nanostructures depends on various factors, especially the concentration of precursors (urea, albumin, and cysteine). Optimum levels of particle size, polydispersity index, zeta potential and particle capacity were obtained at concentrations of albumin $20 \mathrm{mg} / \mathrm{mL}$, cysteine $0.01 \mathrm{mg} / \mathrm{mL}$ and urea $10 \mathrm{mg} / \mathrm{mL}$. This arrangement of nanoparticles with an initial HSA concentration of $20 \mathrm{mg} / \mathrm{mL}$ was relatively stable over time, and analysis of samples over two days showed neither particle aggregation nor destruction of the biopolymer structure. The particle size was kept constant [31]. Therefore, values of $15 \mathrm{mg} / \mathrm{g}$ and $20 \mathrm{mg} / \mathrm{g}$ were chosen as the working range for the initial albumin concentrations. This range of albumin concentrations was also suggested in the study due to the stability of this protein. Although no nanostructures were produced here, it was important that the particles did not change their size in the hydrogel during storage. The addition of albumin in stoichiometric amounts 10 and 100 times smaller did not yield the expected results. [31].

\subsection{Corticotropin Permeation Study from the 1.5\% Hydrogel with Addition Albumin in Stechiometric Ratio 1:1 through Porcine Skin}

The profile of the permeation process of ACTH caused by albumin is shown in Figure 3. Table 5 shows regression coefficients for individual kinetic models of the permeation process and the permeation rate. 


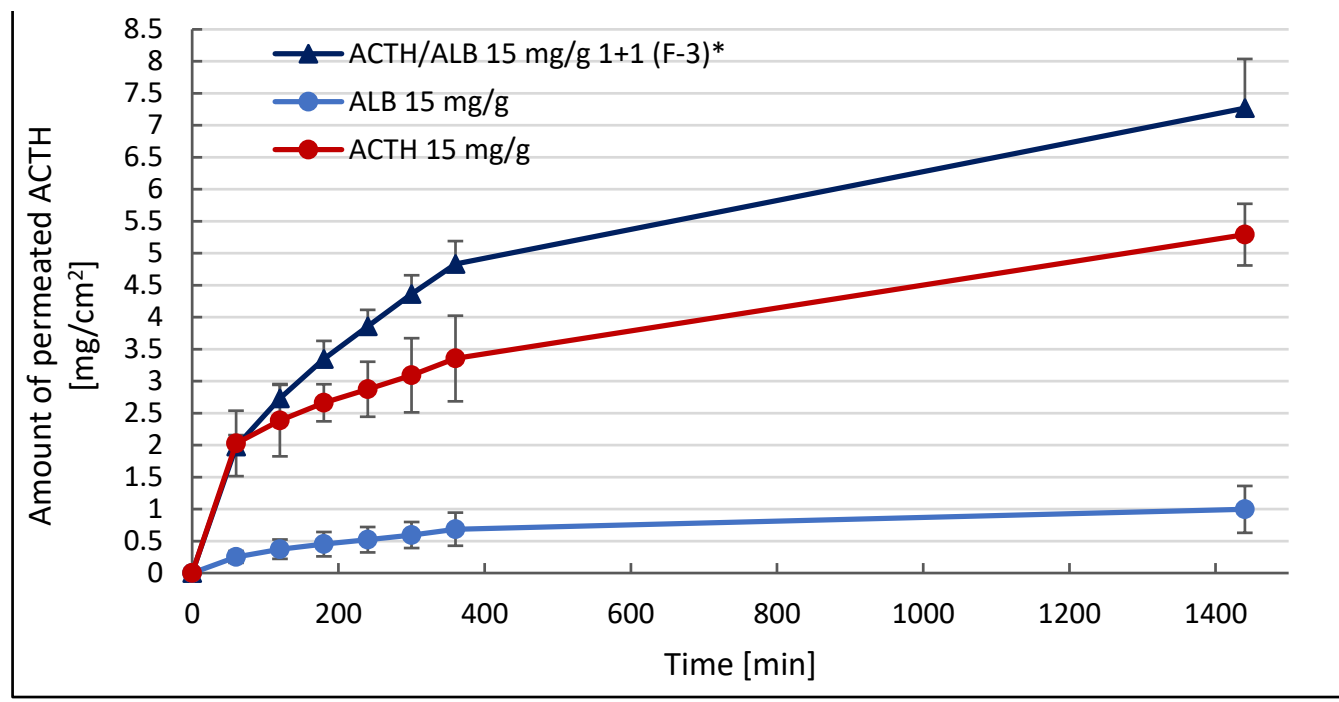

Figure 3. Profiles of ACTH permeation through porcine skin in the presence of albumin in a 1:1 ratio at concentrations of $15 \mathrm{mg} / \mathrm{g}$ ACTH and albumin, from a hydrogel containing only albumin-ALB $15 \mathrm{mg} / \mathrm{g}$ and from a hydrogel containing only ACTH $15 \mathrm{mg} / \mathrm{g}\left({ }^{*} p<0.05\right.$ refer to hydrogel containing only ACTH $15 \mathrm{mg} / \mathrm{g})$.

Table 5. The regression coefficients and average permeation rate of ACTH through the porcine skin in presence of albumin in ratio 1:1 at concentration $15 \mathrm{mg} / \mathrm{g}$ ACTH and albumin, from hydrogel containing albumin-ALB $15 \mathrm{mg} / \mathrm{g}$ and from hydrogel containing ACTH $15 \mathrm{mg} / \mathrm{g}$ ( $p<0.05$ refer to hydrogel containing only ACTH $15 \mathrm{mg} / \mathrm{g}$ ).

\begin{tabular}{|c|c|c|c|c|c|c|}
\hline Formulation & $\begin{array}{l}\text { Zero } \\
\text { Order }\end{array}$ & $\begin{array}{l}\text { First } \\
\text { Order }\end{array}$ & $\begin{array}{l}\text { Higuchi } \\
\text { Model }\end{array}$ & $\begin{array}{c}\text { Korsmeyer-Peppas } \\
\text { Model }\end{array}$ & $\begin{array}{l}\text { Average Permeation Rate } \\
\left(\mathrm{mg} / \mathrm{cm}^{2} / \mathrm{min}^{1 / 2}\right) \pm \mathrm{SD}\end{array}$ & AUC \\
\hline \multicolumn{7}{|c|}{ Regression Coefficient $R^{2}$} \\
\hline F-3 (ACTH + ALB 1:1) & 0.73 & 0.90 & 0.96 & 0.98 & $0.192 \pm 0.020$ * & 7736.19 \\
\hline ACTH 15 mg/g & 0.73 & 0.76 & 0.94 & 0.99 & $0.139 \pm 0.008$ & 5623.76 \\
\hline ALB 15 mg/g & 0.73 & 0.74 & 0.89 & 0.97 & $0.026 \pm 0.010$ * & 1030.35 \\
\hline
\end{tabular}

It was reported that corticotropin $(\mathrm{ACTH})$ penetrates to a more significant extent from semi-solid formulations with lower concentrations. Three concentrations were tested, and it was found that the highest amount of ACTH permeated from hydrogel of $1.5 \%$ $15.07 \pm 2.71 \%$ and the lowest from hydrogel of $2.5 \%-6.95 \pm 0.54 \%$ [12]. The higher the concentration of corticotropin in the hydrogel, the lower the skin permeation.

In the present study, it was observed that the effect of albumin on ACTH release from the resulting hydrogel was greater at the lower concentration, i.e., 1.5\%. For a concentration of $2 \%$, albumin did not significantly increase the amount of ACTH released.

Therefore, the permeation of ACTH through the porcine skin from hydrogel with a concentration of $1.5 \% \mathrm{ACTH}$ and an $\mathrm{ACTH}$ to albumin ratio of $1: 1$ was studied. It was observed that an average of $40.76 \pm 3.51 \%$ ACTH permeated from $1.5 \%$ hydrogel. Compared to the amount of penetrated ACTH in the previous report of Siemiradzka et al. $-15.07 \pm 2.71 \%$ [12], an increase in the amount of penetrated ACTH was observed about 2.7 times. Thus, the rate of penetration is directly influenced by the amount of ACTH penetrating, which can be expressed in $\mathrm{mg} / \mathrm{cm}^{2}\left(5.29 \pm 0.48 \mathrm{mg} / \mathrm{cm}^{2}\right)$ or as a part of the dose applied to the skin in \% (30.5\%). An increase in ACTH permeation under the in-fluence of albumin permeation per unit area was found from $5.29 \pm 0.48 \mathrm{mg} / \mathrm{cm}^{2}$ $(30.5 \%)$ for ACTH alone to $7.27 \pm 0.77 \mathrm{mg} / \mathrm{cm}^{2}(41.92 \%)$ for hydrogel containing ACTH and albumin in the ratio $1: 1$ of $15 \mathrm{mg} / \mathrm{g}$ hydrogel $(p<0.05)$. If albumin increases the amount of ACTH permeated through the skin to $7.27 \pm 0.77 \mathrm{mg} / \mathrm{cm}^{2}$ (up to $41.92 \%$-about 
a 1.4-fold increase), the permeation rate also increased (Table 5) 1.4-fold from $0.139 \pm 0.008$ to $0.192 \pm 0.020 \mathrm{mg} / \mathrm{cm}^{2} / \mathrm{min}^{1 / 2}$.

This can also be demonstrated by measuring the area under the AUC permeation curve. For the hydrogel containing $15 \mathrm{mg} / \mathrm{g}$ ACTH, the AUC was 5623.756, while in the presence of 1:1 albumin, the AUC was 7736.197, making a 1.4-fold increase in the area under the curve Table 5). For comparison, a study on the penetration of albumin from the hydrogel was also performed. It was found that albumin itself penetrated less than ACTH and ACTH together with albumin $\left(0.99 \pm 0.37 \mathrm{mg} / \mathrm{cm}^{2}\right)$. Binding to plasma proteins protects compounds from oxidation, reduces their toxicity and prolongs their half-life; drugs that are strongly bound to plasma proteins often show low first-pass metabolism [32,33].

Increasing the efficiency of skin permeation of various drugs can be aided by various techniques for conducting transport substances into nanoparticles. Gaurav et al. prepared transferosomes also named ultra-deformable liposomes. These deformable vesicles can transport drug through the skin, which is the largest human organ with a total mass of $3 \mathrm{~kg}$ and an area of $1.5-2.0 \mathrm{~m}^{2}$. The size of this organ favours efficient delivery of both low and high molecular weight drugs through transferosomes. The prepared transferosomal formulations were evaluated for uptake efficiency, stability and skin penetration ability. It was found that ultra-deformable liposomes can be used to deliver various drugs, e.g., analgesics, anaesthetics, corticosteroids, anticancer drugs, sex hormones, insulin, proteins including albumin [34].

In percutaneous administration, the corneal layer of the epidermis tends to impede the absorption of drugs through the skin. However, albumin nanoparticles can bypass this barrier by delivering them through hair follicles. Additionally, nanoparticles can be retained in hair follicles for a much longer period of time. This would enable systemic absorption and local action as well as possible permanent release [35].

At present, nanoparticles show great potential as carriers of new drugs in percutaneous drug delivery. Smaller nanoparticle sizes can ensure a tight contact with the stratum corneum and enhance skin permeation. The advantage of using such colloidal carriers is to protect sensitive drugs from destruction and to control the rate of drug release from such carriers. Nanoparticles have dimensions ranging from $1 \mathrm{~nm}$ to $1000 \mathrm{~nm}$ [36-39]. Currently, researchers' interests are focused on polymeric nanoparticles due to their stability and ability to specifically modify the surface [40]. A significantly higher permeation flux of aceclofenac $\left(0.0681 \pm 0.0008 \mathrm{~g} / \mathrm{cm}^{2} / \mathrm{h},(p<0.05)\right.$ was confirmed from a Carbopol 940 gel containing chitosan, albumin and aceclofenac nanoparticles than for a commercially available aceclofenac gel $\left(0.0316 \pm 0.0004 \mathrm{~g} / \mathrm{cm}^{2} / \mathrm{h}\right)$. Aceclofenac is a non-steroidal antiinflammatory drug (NSAID) with a short half-life $(4 \mathrm{~h})$, used for the treatment of pain and inflammation [41-43]. Shokri and Javar in turn studied the strengthening effect of zinc oxide and calcium phosphate nanoparticles on the total penetration of albumin through a part of a full mouse skin cut from the back of the mouse. The enhancing effect of albumin permeation under zinc oxide nanoparticles was stronger, whereas it was faster under calcium phosphate nanoparticles. The most albumin penetrated in the presence of zinc oxide and it was reached in $1.5 \mathrm{~h}(40.2 \pm 3.6 \mathrm{mg})$, while in the presence of calcium phosphate maximum was achieved in $1 \mathrm{~h}$, and the amount permeated was $33.8 \pm 5.5 \mathrm{mg}$ [44].

\subsection{Effect of Albumin on the Rheological Properties of Prepared Hydrogels with ACTH}

In the present study, the viscosity of prepared hydrogel formulations was determined at $32.0 \pm 0.5^{\circ} \mathrm{C}$ at two shear rates: $15 \mathrm{~s}^{-1}$ and $30 \mathrm{~s}^{-1}$. The examined viscosity and shear stress values are presented in Table 6. 
Table 6. Viscosity parameters of formulations determined at $32{ }^{\circ} \mathrm{C}$ at two selected shear rates.

\begin{tabular}{|c|c|c|c|c|}
\hline \multirow{3}{*}{ Formulation } & \multicolumn{4}{|c|}{ Shear Rate } \\
\hline & \multicolumn{2}{|c|}{$15 s^{-1}$} & \multicolumn{2}{|c|}{$30 s^{-1}$} \\
\hline & Shear Stress [Pa] & Viscosity [Pa.s] & Shear Stress [Pa] & Viscosity [Pa.s] \\
\hline F-1 & $90.10 \pm 11.32$ & $6.01 \pm 0.76$ & $182.52 \pm 20.81$ & $6.08 \pm 0.70$ \\
\hline $\mathrm{F}-2$ & $113.89 \pm 2.77 *$ & $7.59 \pm 0.19^{*}$ & $155.80 \pm 7.08$ * & $5.19 \pm 0.24 *$ \\
\hline F-3 & $73.66 \pm 0.47^{*}$ & $4.91 \pm 0.03 *$ & $97.93 \pm 5.36^{*}$ & $3.26 \pm 0.18^{*}$ \\
\hline F-4 & $113.96 \pm 2.31$ * & $7.60 \pm 0.15^{*}$ & $149.40 \pm 5.87$ * & $4.98 \pm 0.20 *$ \\
\hline F-5 & $94.24 \pm 1.91$ & $6.28 \pm 0.13$ & $127.42 \pm 5.01$ * & $4.25 \pm 0.17^{*}$ \\
\hline F-6 & $137.71 \pm 2.51 *$ & $9.20 \pm 0.17 *$ & $176.17 \pm 6.17$ & $5.87 \pm 0.21$ \\
\hline F-7 & $91.85 \pm 1.74$ & $6.12 \pm 0.12$ & $117.52 \pm 4.65$ * & $3.92 \pm 0.16^{*}$ \\
\hline F-8 & $94.44 \pm 1.76$ & $6.30 \pm 0.12$ & $143.42 \pm 7.02$ * & $4.78 \pm 0.23^{*}$ \\
\hline F-9 & $109.82 \pm 2.51$ * & $7.32 \pm 0.17^{*}$ & $150.25 \pm 4.24$ * & $5.02 \pm 0.14 *$ \\
\hline
\end{tabular}

* significance statistical difference refer to F-1 formulation $(p<0.01)$.

A decrease in viscosity with increasing shear rate was observed in all tested formulations. For shear rate $\mathrm{D}=15 \mathrm{~s}^{-1}$, the highest value of structural viscosity was observed for the hydrogel with higher ACTH concentration $(20 \mathrm{mg} / \mathrm{g} ; 9.20 \pm 0.17 \mathrm{~Pa} \cdot \mathrm{s})$, while the hydrogels with lower ACTH concentration-F-2 (7.59 $\pm 0.19 \mathrm{~Pa} \cdot \mathrm{s})$ showed lower viscosity. Thus, the addition of ACTH increases the viscosity of the tested hydrogels. The addition of $15 \mathrm{mg} / \mathrm{g}$ ACTH causes an approximately 1.3-fold increase in viscosity, while the addition of $20 \mathrm{mg} / \mathrm{g}$ ACTH causes a 1.5-fold increase in viscosity for both shear rates (D $=15 \mathrm{~s}^{-1}$ and $\left.\mathrm{D}=30 \mathrm{~s}^{-1}\right)$. Albumin, in turn, causes a decrease in viscosity, the more albumin, the greater the decrease in viscosity. Albumin added to hydrogels in a 1:1 ratio to ACTH causes a decrease in viscosity by about 1.6 times at both shear rates $\left(D=15 \mathrm{~s}^{-1}\right.$ and $\left.\mathrm{D}=30 \mathrm{~s}^{-1}\right)$ at a concentration of $15 \mathrm{mg} / \mathrm{g}$ and by about 1.5 times at a concentration of $20 \mathrm{mg} / \mathrm{g}$. As the addition of albumin was reduced, the viscosity gradually increased compared to hydrogels with ACTH without albumin.

The relationship between shear rate and viscosity is shown in Figure 4A,B. The study was carried out in the range $\mathrm{D}=5-200 \mathrm{~s}^{-1}$.

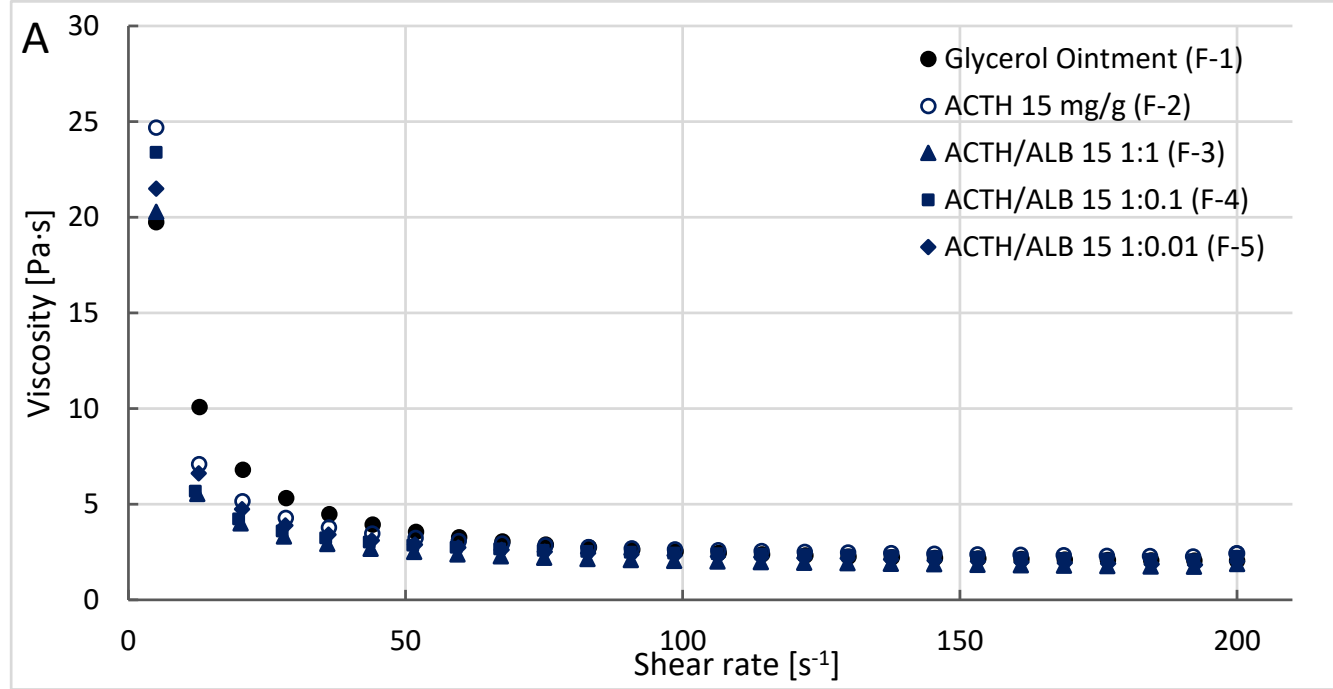

Figure 4. Cont. 


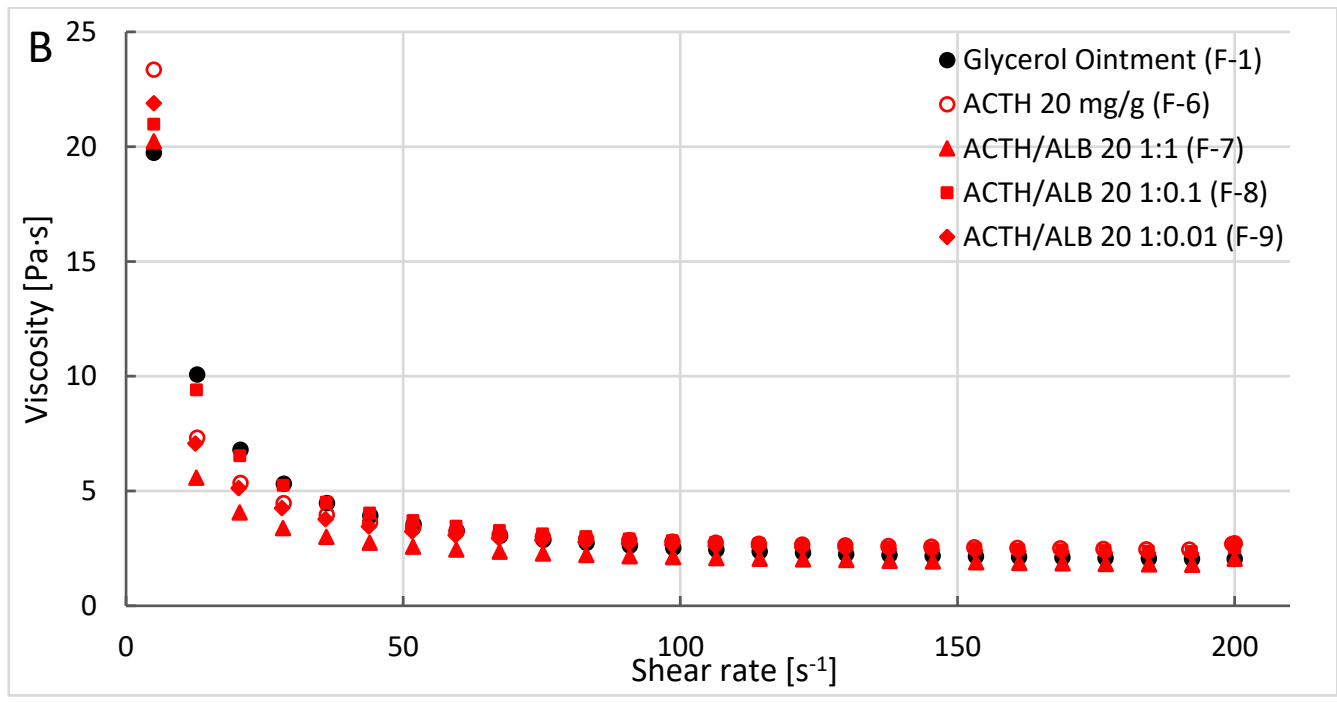

Figure 4. Viscosity curves for formulations containing ACTH at concentration $15 \mathrm{mg} / \mathrm{g}$ (F-2) and ACTH at concentration $15 \mathrm{mg} / \mathrm{g}$ and albumin (F-3-F-5) (A) and for formulations containing ACTH at concentration $20 \mathrm{mg} / \mathrm{g}$ (F-6) and for formulations containing ACTH at concentration $20 \mathrm{mg} / \mathrm{g}$ and albumin (F-7-F-9) (B) with regard to Glycerol hydrogel-F-1, $n=5$.

All hydrogels showed an inversely proportional relationship between viscosity and shear rate or stress, which indicates the shear properties of these hydrogels. This observation indicates that the hydrogels can be easily applied to the skin each time a different shear rate is applied.

The relationship between shear rate $(\gamma)$ and stress $(\tau)$ is shown in Figure 5A,B. With increasing shear rate of hydrogels, the stress values increased. As the shear rate decreased, the hydrogel structure was restored. Weak bonds between the molecules of the system were ruptured, while after decreasing the shear rate, the bonds between the molecules were regenerated and the hydrogel structure was restored. The flow curves for all hydrogels were concave to the horizontal axis. This indicates a pseudoplastic character, which allowed the hydrogels to return to their original rheological state.

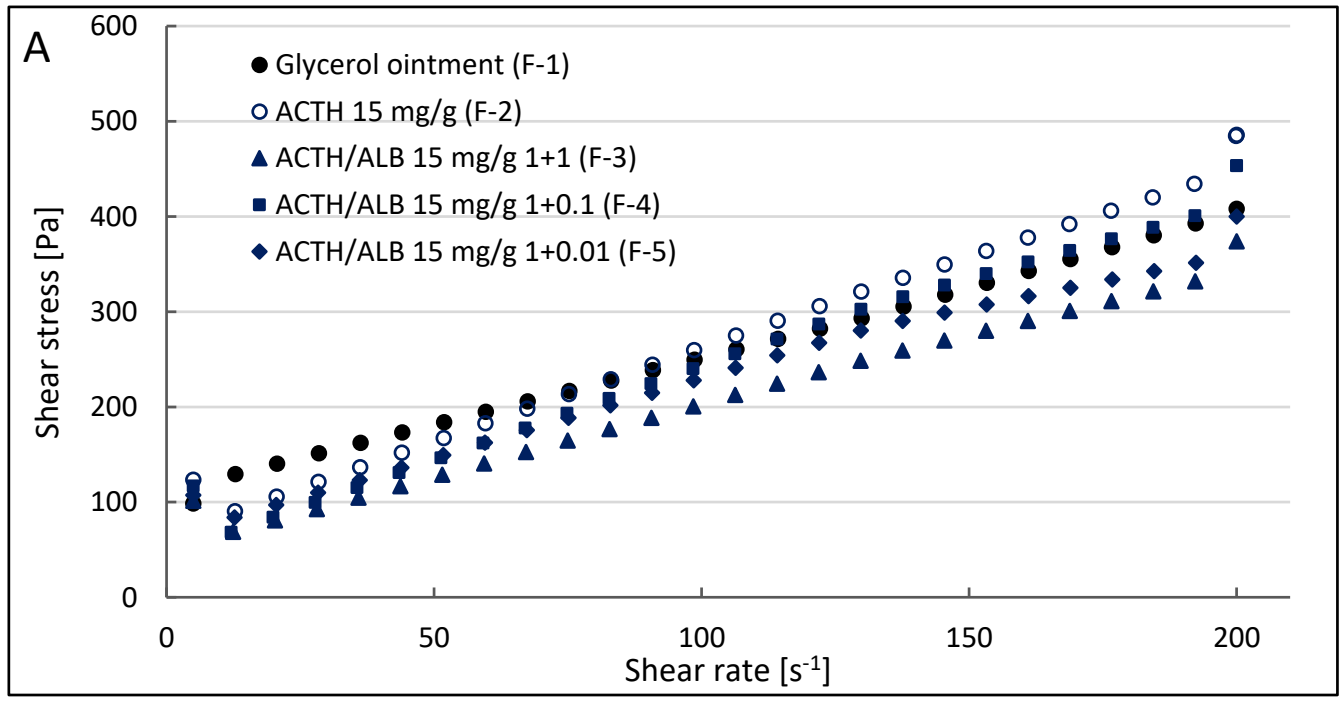

Figure 5. Cont. 


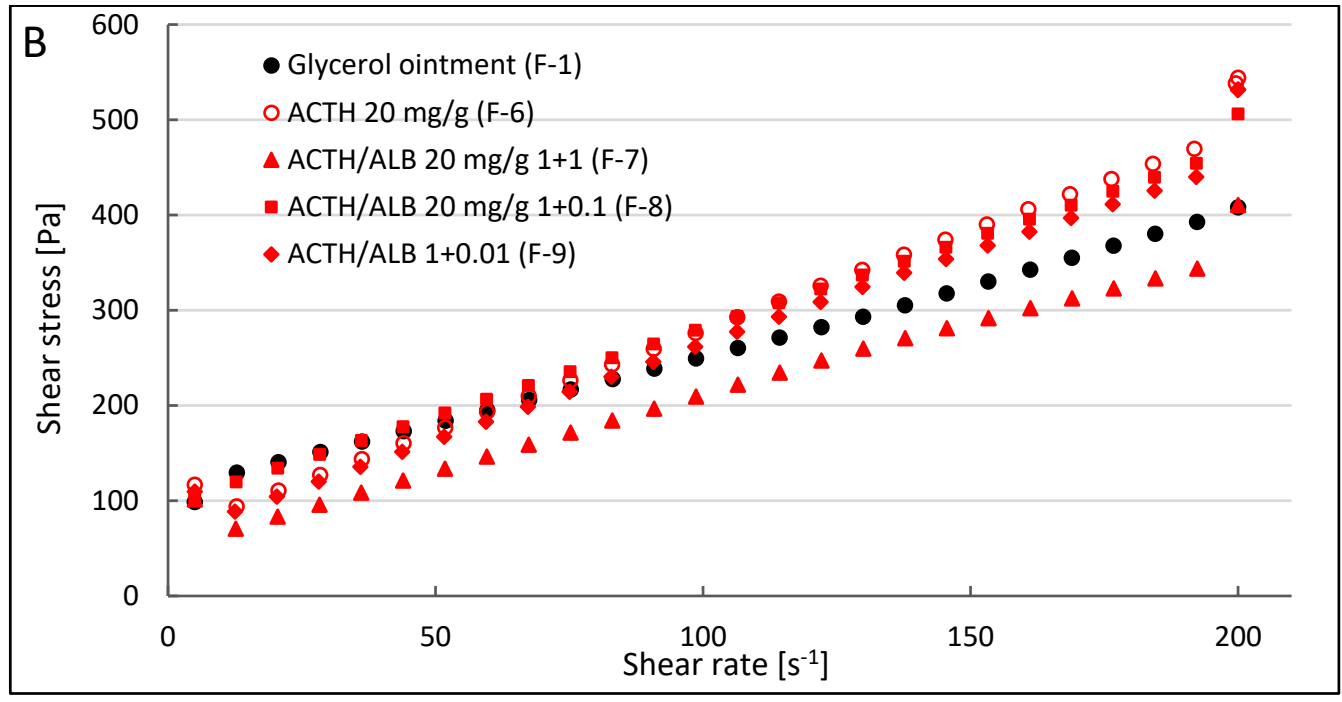

Figure 5. Flow curves for formulations containing ACTH at concentration $15 \mathrm{mg} / \mathrm{g}$ (F-2) and ACTH at concentration $15 \mathrm{mg} / \mathrm{g}$ and albumin (F-3-F-5) (A) and for formulations containing ACTH at concentration $20 \mathrm{mg} / \mathrm{g}$ (F-6) and for formulations containing ACTH at concentration $20 \mathrm{mg} / \mathrm{g}$ and albumin (F-7-F-9) (B) with regard to Glycerol hydrogel-F-1, $n=5$.

The relatively small area formed between ascending and descending curves indicated good regeneration of the systems (Figure 6A,B). A system with good regeneration could increase adhesion on the skin and thus maintain a better therapeutic effect.

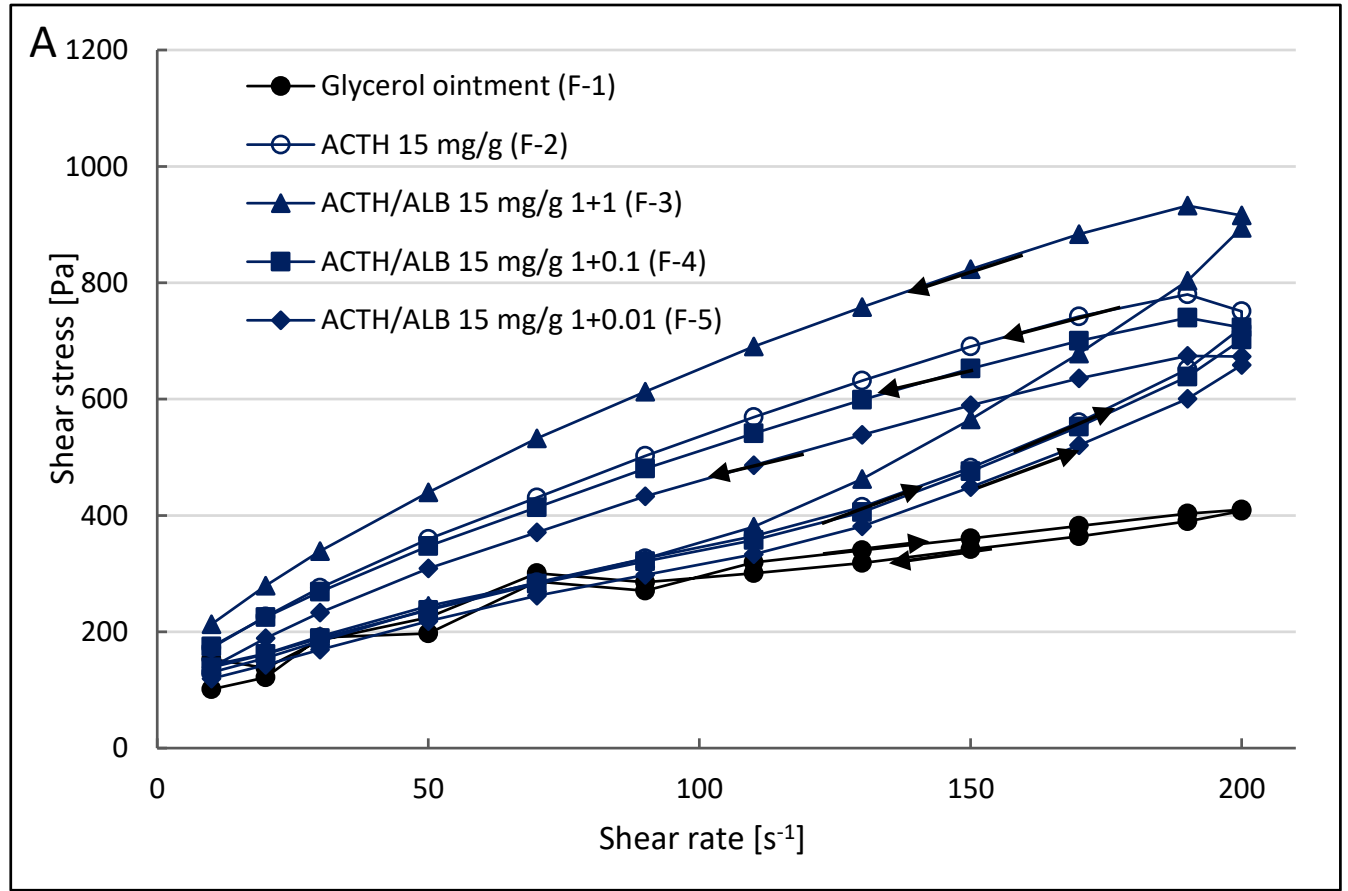

Figure 6. Cont. 


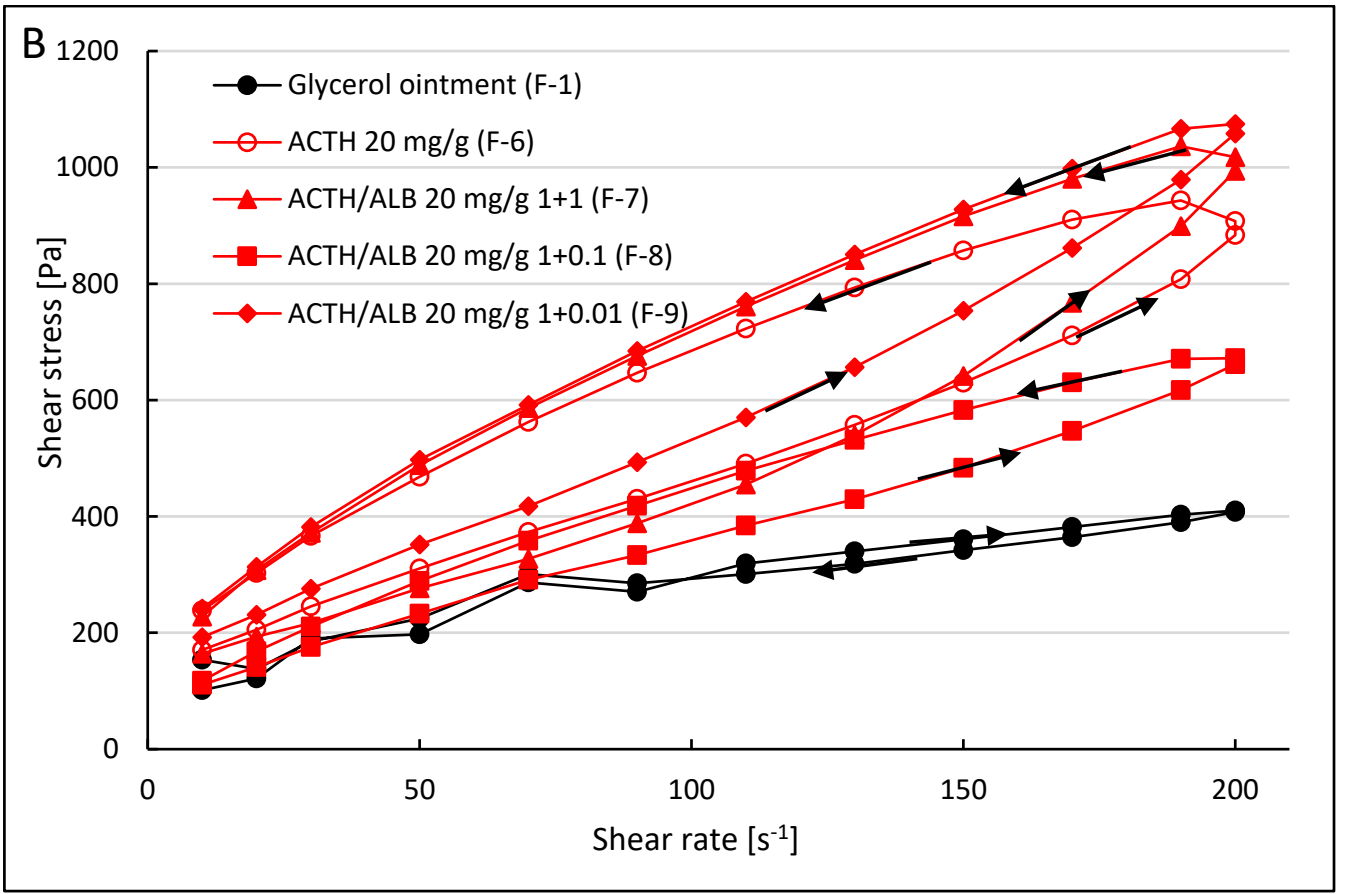

Figure 6. Hysteresis loops for preparations containing $15 \mathrm{mg} / \mathrm{g}$ ACTH (F-2) and $15 \mathrm{mg} / \mathrm{g} \mathrm{ACTH}$ and albumin: 1:1; 1:0.1; 1:0.01 (F-3-F-5) (A) and for formulations containing $20 \mathrm{mg} / \mathrm{g}$ ACTH (F-6) and $20 \mathrm{mg} / \mathrm{g}$ ACTH and albumin: 1:1; 1:0.1; 1:0.01 (F-7-F-9) (B) compared to glycerol hydrogel-F-1, $n=5.4$.

\section{Discussion}

Since albumin has an isoelectric point (pI) of 4.25, under physiological $\mathrm{pH}$ conditions it exists as an anion with a very dense negative charge. In addition, carboxyl and amino groups present on the albumin surface, allow binding to albumin through covalent or non-covalent bonds $[45,46]$. On the other hand, albumin negative charge densification further enhances albumin stability and ensures its long-term circulation in the blood due to intense repulsion from negatively charged serum proteins [45,47-49]. Hyaluronic acid has a moisturising and repairing function as a component of the skin matrix. Due to its molecular weight much higher than $500 \mathrm{Da}$, it has difficulty penetrating into deeper skin layers.

Martins et al. prepared nanodispersions by obtaining a complex between a sucrose ester surfactant and a protein with hyaluronic acid. This was formed by high-pressure homogenisation. Lyophilisation was then carried out to obtain a solid surfactant-protein complex. This complex was transformed into a solid-in-oil (S/O) nanodispersion with oil, isopropyl myristate (IPM), using ultrasound. The average diameter of the nanodispersion was $129.7 \mathrm{~nm}$, showing good stability both physically and biologically [50]. With the penetration of the nanodispersion, BSA can be hydrolysed by proteases in the skin environment, allowing HA penetration into deeper skin layers [45].

In the study of permeation of model protein-peptide substances through the pericardium, the amount of permeation of selected substances from $1.0 \mathrm{mg} / \mathrm{mL}$ solutions was examined under simulated in vivo model conditions. The obtained results confirmed that all tested substances-ACTH, INS, PRL, HSA, permeate through the natural membranepericardium. Possible differences in permeation may result from significant differences in the structure and physicochemical properties of selected substances. In the present study, it was observed that the higher molecular weight of the substances studied, the longer time of their permeation through the pericardium [25].

Another study simulated the conditions of absorption and permeation of prolactin (PRL) from solutions of different compositions intended for oral administration across a natural membrane (small intestine of the suckling piglet) under in vivo conditions. Pro- 
lactin is a protein-peptide hormone with a molecular weight of $\sim 23.4 \mathrm{kDa}$. It was found that the absorption of PRL in the small intestine of the suckling piglet was significantly dependent on the concentration of the hormone and trehalose in solution. In turn, the permeation process of PRL in the studied range is influenced by all studied factors (hormone concentration, trehalose and mannitol concentration, $\mathrm{pH}$ value of the solution) [51].

\section{Conclusions}

The results suggest that albumin added to corticotropin hydrogels delayed the release of ACTH from almost all formulations to which it was added in an amount less than ACTH except formulation F-3 (ACTH and albumin $15 \mathrm{mg} / \mathrm{g}: 15 \mathrm{mg} / \mathrm{g}$, in an equivalent ratio of 1:1). Albumin had the best effect at a concentration of $15 \mathrm{mg} / \mathrm{g}$ in a 1:1 ratio to ACTH (F-3). In this formulation, albumin significantly increased the ACTH release process. In a formulation with a higher ACTH concentration of $20 \mathrm{mg} / \mathrm{g}$ (F-7), albumin initially caused a decrease in the amount of ACTH released and then an increase, but the increase in the amount of ACTH was not statistically significant.

The results obtained so far indicate that albumin penetrates natural membranes and may affect the transport of other macromolecular substances, e.g., corticotropin. This suggests the possibility of attempts to formulate a transdermal drug delivery system in a convenient form for the patient and in a non-invasive way.

Author Contributions: Conceptualization, W.S., B.D. and F.R.; methodology, W.S.; software, W.S.; validation, W.S., B.D. and F.R.; formal analysis, W.S.; investigation, W.S.; resources, B.D., F.R.; data curation, W.S., B.D. and F.R.; writing-original draft preparation, W.S.; writing-review and editing, W.S.; visualization, W.S.; supervision, W.S. and B.D.; project administration, W.S., B.D. and F.R.; funding acquisition, B.D. and F.R. All authors have read and agreed to the published version of the manuscript.

Funding: The research was with funds for a project financed by the Medical University of Silesia in Katowice No. PCN-1-191/K/0/F "Studies on the development of semi-solid and liquid dosage forms with model protein-peptide substances".

Institutional Review Board Statement: Not applicable.

Informed Consent Statement: Not applicable.

Data Availability Statement: Samples of the formulations are available from the authors.

Conflicts of Interest: The authors declare no conflict of interest.

\section{References}

1. Li, N.; Larin, E.M.; Kerman, K. A Miniaturized impedimetric immunosensor for the competitive detection of adrenocrticotropic hormone. Sensor 2017, 17, 2836. [CrossRef]

2. Clark, A.J.; Forfar, R.; Hussain, M.; Jerman, J.; McIver, E.; Taylor, D.; Chan, L. ACTH Antagonists. Front. Endocrinol. $2016,7,101$. [CrossRef] [PubMed]

3. Gallo-Payet, N. 60 Years of POMC: Adrenal and extra-adrenal functions of ACTH. J. Mol. Endocrinol. 2016, 56, 135-156. [CrossRef]

4. Fleseriu, M.; Findling, J.W.; Koch, C.A.; Schlaffer, S.M.; Buchfelder, M.; Gross, C. Changes in plasma ACTH levels and corticotroph tumor size in patients with Cushing's disease during long-term treatment with the glucocorticoid receptor antagonist mifepristone. J. Clin. Endocrinol. Metab. 2014, 99, 3718-3727. [CrossRef] [PubMed]

5. Montero-Melendez, T. ACTH: The forgotten therapy. Semin. Immunol. 2015, 27, 216-226. [CrossRef]

6. Philbin, M.; Niewoehner, J.; Wan, G.J. Clinical and Economic Evaluation of Repository Corticotropin Injection: A Narrative Literature Review of Treatment Efficacy and Healthcare Resource Utilization for Seven Key Indications. Adv. Ther. 2017, 34, 1775-1790. [CrossRef]

7. Vandael, D.; Gounko, N.V. Corticotropin releasing factor-binding protein (CRF-BP) as a potential new therapeutic targetin Alzheimer's disease and stress disorders. Transl. Psychiatry 2019, 9, 272. [CrossRef] [PubMed]

8. Berkovich, R.; Agius, M. Mechanisms of action of ACTH in the management of relapsing forms of multiple sclerosis. Ther. Adv. Neurol. Disord. 2014, 7, 83-96. [CrossRef]

9. Loram, L.; Culp, M.; Connolly-Strong, E. Melanocortin Peptides: Potential Targets in Systemic Lupus Erythematosus. Inflammation 2015, 38, 260-271. [CrossRef] 
10. Berkovich, R.; Bakshi, R.; Amezcua, L.; Axtell, R.C.; Cen, S.Y.; Tauhid, S.; Neema, M.; Steinman, L. Adrenocorticotropic hormone versus methylprednisolone added to interferon $\beta$ in patients with multiple sclerosis experiencing breakthrough disease: $\mathrm{A}$ randomized, rater-blinded trial. Ther. Adv. Neurol. Disord. 2017, 10, 3-17. [CrossRef]

11. Siemiradzka, W.; Dolińska, B.; Ryszka, F. Development and Study of Semi-Solid Preparations Containing the Model Substance Corticotropin (ACTH): Convenience Application in Neurodegenerative Diseases. Molecules 2020, 25, 1824. [CrossRef] [PubMed]

12. Siemiradzka, W.; Dolińska, B.; Ryszka, F. Influence of Concentration on Release and Permeation Process of Model Peptide Substance-Corticotropin-From Semisolid Formulations. Molecules 2020, 25, 2767. [CrossRef] [PubMed]

13. Wunder, A.; Muller-Ladner, U.; Stelzer, E.H.; Funk, J.; Neumann, E.; Stehle, G.; Pap, T.; Sinn, H.; Gay, S.; Fiehn, C. Albumin-based drug delivery as novel therapeutic approach for rheumatoid arthritis. J. Immunol. Methods 2003, 170, 4793-4801. [CrossRef]

14. Tao, C.; Chuah, Y.J.; Xu, C.J.; Wang, D.A. Albumin conjugates and assemblies as versatile bio-functional additives and carriers for biomedical applications. J. Mater. Chem. B 2019, 7, 357-367. [CrossRef] [PubMed]

15. Anbouhi, T.S.; Esfidvajani, E.M.; Nemati, F. Albumin binding, anticancer and antibacterial properties of synthesized zero valent iron nanoparticles. Int. J. Nanomed. 2018, 14, 243-256. [CrossRef]

16. Mou, J.; Liu, Z.; Liu, J.; Lu, J.; Zhu, W.; Pei, D. Hydrogel containing minocycline and zinc oxide-loaded serum albumin nanopartical for periodontitis application: Preparation, characterization and evaluation. Drug Deliv. 2019, 26, 179-187. [CrossRef]

17. Bernardi, M.; Ricci, C.S.; Zaccherini, G. Role of human albumin in the management of complications of liver cirrhosis. J. Clin. Exp. Hepatol. 2014, 4, 302-311. [CrossRef]

18. Chytil, P.; Koziolova, E.; Etrych, T.; Ulbrich, K. HPMA Copolymer-Drug Conjugates with Controlled Tumor-Specific Drug Release. Macromol. Biosci. 2018, 18, 1700209. [CrossRef]

19. Sun, J.H.; Ye, C.; Bai, E.H.; Zhang, L.L.; Huo, S.J.; Yu, H.H.; Xiang, S.Y.; Yu, S.Q. Co-delivery nanoparticles of doxorubicin and chloroquine for improving the anti-cancer effect in vitro. Nanotechnology 2019, 8, 085101. [CrossRef]

20. Rahimizadeh, P.; Yang, S.; In Lim, S. Albumin: An Emerging Opportunity in Drug Delivery. Biotechnol. Bioprocess Eng. 2020, 25, 985-995. [CrossRef]

21. Pilati, D.; Howard, K.A. Albumin-based drug designs for pharmacokinetic modulation. Expert Opin. Drug Metab. Toxicol. 2020, 16, 9. [CrossRef] [PubMed]

22. Sethi, A.; Sher, M.; Akram, M.R.; Karim, S.; Khiljee, S.; Sajjad, A.; Shah, S.N.; Murtaza, G. Albumin as a drug delivery and diagnostic tool and its market approved products. Acta Pol. Pharm. 2013, 70, 597-600. [PubMed]

23. Kratz, F. A clinical update of using albumin as a drug vehicle-A commentary. J. Control. Release 2014, 190, 331-336. [CrossRef] [PubMed]

24. Van de Sande, L.; Cosyns, S.; Willaert, W.; Ceelen, W. Albumin-based cancer therapeutics for intraperitoneal drug delivery: A review. Drug Deliv. 2020, 27, 40-53. [CrossRef]

25. Dolińska, B.; Siemiradzka, W.; Ryszka, F. Penetration of model hormones through the pericardium in simulated conditions in vivo. Biomed. Pharmacother. 2020, 127, 110113. [CrossRef]

26. Office for Registration of Medicinal Products. Medical Devices and Biocidal Products, Polish Pharmacopoeia, 6th ed.; Polskie Towarzystwo Farmaceutyczne: Warsaw, Poland, 2002; p. 921.

27. Office for Registration of Medicinal Products. Medical Devices and Biocidal Products, Polish Pharmacopoeia, 11th ed.; Polskie Towarzystwo Farmaceutyczne: Warsaw, Poland, 2017; Volume 3, p. 142.

28. Caon, T.; Costa, A.C.; de Oliveira, M.A.; Micke, G.A.; Simoes, C.M. Evaluation of the transdermal permeation of di_erent paraben combinations through a pig ear skin model. Int. J. Pharm. 2010, 391, 1-6. [CrossRef] [PubMed]

29. Arabi, S.H.; Aghelnejad, B.; Schwieger, C.; Meister, A.; Kerth, A.; Hinderberger, D. Serum albumin hydrogels in broad pH andtemperature ranges: Characterization of their self-assembled structures and nanoscopic and macroscopic properties. Biomater. Sci. 2018, 6, 478-492. [CrossRef] [PubMed]

30. Baler, K.; Michael, R.; Szleifer, I.; Ameer, G.A. Albumin hydrogels formed by electrostatically triggered self-assembly and their drug delivery capability. Biomacromolecules 2014, 15, 3625-3633. [CrossRef]

31. Tazhbayev, Y.; Mukashev, O.; Burkeev, M.; Kreuter, J. Hydroxyurea-Loaded Albumin Nanoparticles: Preparation, Characterization, and In Vitro Studies. Pharmaceutics 2019, 11, 410. [CrossRef]

32. Svennebring, A. The connection between plasma protein binding and acute toxicity as determined by the LD50 value. Drug. Dev. Res. 2016, 77, 3-11. [CrossRef]

33. Zhang, F.; Xue, J.; Shao, J.; Jia, L. Compilation of 222 drugs' plasma protein binding data and guidance for study designs. Drug Discov. Today 2012, 17, 475-485. [CrossRef] [PubMed]

34. Tiwari, G.; Tiwari, R.; Singh, R.; Rai, A.K. Ultra-deformable Liposomes as Flexible Nanovesicular Carrier to Penetrate Versatile Drugs Transdermally. Nanosci. Nanotechnol.-Asia 2020, 10, 12-20. [CrossRef]

35. Tan, Y.L.; Ho, H.K. Navigating albumin-based nanoparticles through various drug delivery routes. Drug Discov. Today 2018, 23, 1108-1114. [CrossRef] [PubMed]

36. Tomoda, K.; Watanabe, A.; Suzuki, K.; Inagi, T.; Terada, H.; Makino, K. Enhanced transdermal permeability of estradiol using combination of PLGA nanoparticle system and iontophoresis. Colloids Surf. B Biointerfaces 2012, 97, 84-89. [CrossRef]

37. Tomoda, K.; Tarashima, H.; Suzuki, K.; Inagi, T.; Terada, H.; Makino, K. Enhanced transdermal delivery of indomethacin using combination of PLGA nanoparticles and iontophoresis in vivo. Colloids Surf. B Biointerfaces 2012, 92, 50-54. [CrossRef]

38. Pal, D.; Nayak, A.K. Nanotechnology for targeted delivery in cancer therapeutics. Int. J. Pharm. Sci. Rev. Res. 2010, 1, 1-7. 
39. Malakar, J.; Ghosh, A.; Basu, A.; Nayak, A.K. Nanotechnology a promising carrier for intracellular drug delivery system. Int. Res. J. Pharm. 2012, 3, 36.

40. Pawar, H.; Douroumis, D.; Boateng, J.S. Preparation and optimization of PMMA-chitosan-PEG nanoparticles for oral drug delivery. Colloids Surf. B Biointerfaces 2012, 90, 102. [CrossRef]

41. Jana, S.; Saha, A.; Nayak, A.K.; Sen, K.K.; Basu, S.K. Aceclofenac-loaded chitosan-tamarind seed polysaccharide interpenetrating polymeric network microparticles. Colloids Surf. B Biointerfaces 2013, 105, 303-309. [CrossRef]

42. Jana, S.; Das, A.; Nayak, A.K.; Sen, K.K.; Basu, S.K. Aceclofenac-loaded unsaturated esterified alginate/gellan gum microspheres: In vitro and in vivo assessment. Int. J. Biol. Macromol. 2013, 57, 129-137. [CrossRef]

43. Jana, S.; Manna, S.; Nayak, A.K.; Sen, K.K.; Basu, S.K. Carbopol gel containing chitosan-egg albumin nanoparticles for transdermal aceclofenac delivery. Colloids and Surfaces B Biointerfaces 2014, 114, 36-44. [CrossRef] [PubMed]

44. Shokri, N.; Javar, H.A. Comparison of Calcium Phosphate and Zinc Oxide Nanoparticles as Dermal Penetration Enhancers for Albumin. Indian J. Pharm. Sci. 2015, 77, 694-704. [CrossRef] [PubMed]

45. Lei, C.; Liu, X.R.; Chen, Q.B.; Li, Y.; Zhou, J.L.; Zhou, L.Y.; Tao Zou, T. Hyaluronic acid and albumin based nanoparticles for drug delivery. J. Control. Release 2021, 331, 416-433. [CrossRef]

46. Quinlan, G.J.; Martin, G.S.; Evans, T.W. Albumin: Biochemical properties and therapeutic potential. Hepatology 2005, 41, 1211-1219. [CrossRef] [PubMed]

47. Hobbs, S.K.; Monsky, W.L.; Yuan, F.; Roberts, W.G.; Griffith, L.; Torchilin, V.P. Regulation of transport pathways in tumor vessels: Role of tumor type and microenvironment. Proc. Natl. Acad. Sci. USA 1998, 95, 4607-4612. [CrossRef]

48. Shen, Z.Y.; Li, Y.; Kohamab, K.; Oneilla, B.; Bi, J.X. Improved drug targeting of cancer cells by utilizing actively targetable folic acid-conjugated albumin nanospheres. Pharmacol. Res. 2011, 63, 51-58.

49. Chacon, M.; Molpeceres, J.; Berges, L.; Guzman, M.; Aberturas, M.R. Stability and freeze-drying of cyclosporine loaded poly [D, L lactide-glycolide] carriers. Eur. J. Pharm. Sci. 1999, 8, 99-107. [CrossRef]

50. Martins, M.; Azoia, N.G.; Shimanovich, U.; Matam 'a, T.; Gomes, A.C.; Silva, C.; Cavaco-Paulo, A. Design of novel BSA/hyaluronic acid nanodispersions for transdermal pharma purposes. Mol. Pharm. 2014, 11, 1479-1488. [CrossRef]

51. Dolińska, B.; Siemiradzka, W.; Ryszka, F. Effectiveness of absorption and passage through the small intestine, as a model of oral prolactin administration. Biomed. Pharmacother. 2019, 120, 109515. [CrossRef] 